\title{
PELATIHAN PEMBUATAN KEMASAN SABUN BUNGA MATAHARI DI DESA BOJONGHALEUANG SEBAGAI PROGRAM COMMUNITY EMPOWERMENT
}

\author{
Dewi Isma Aryani', Nina Nurviana ${ }^{2}$, dan Heddy Heryadi ${ }^{2}$
}

\begin{abstract}
1Program Studi D-3 Seni Rupa dan Desain, Fakultas Seni Rupa dan Desain, Universitas Kristen Maranatha Jl. Prof. drg. Suria Sumantri, MPH no.65, Bandung, 40164, Indonesia.

${ }^{2}$ Program Studi Desain Komunikasi Visual, Fakultas Seni Rupa dan Desain, Universitas Kristen Maranatha Jl. Prof. drg. Suria Sumantri, MPH no.65, Bandung, 40164, Indonesia.
\end{abstract}

Email: dewi.ia@art.maranatha.edu

\begin{abstract}
ABSTRAK
Universitas Kristen Maranatha sebagai salah satu universitas swasta di Bandung memiliki program kerja yang tercermin dalam visi dan misi tridharma perguruan tinggi. Visi dan misi Universitas Kristen Maranatha yang dilakukan melalui bidang pengajaran, penelitian dan pengabdian masyarakat, salah satunya difokuskan pada program pemberdayaan masyarakat dan permasalahan sosial di sekitar, melibatkan beberapa dosen dari perwakilan Program Studi Desain Komunikasi Visual dan D-3 Seni Rupa Desain sebagai perumus materi sekaligus pelatih atau pengajar keterampilan sebagai wujud tanggung jawab sosial tersebut. Program pengabdian kepada masyarakat yang digagas berupa pelatihan pembuatan kemasan produk sabun dari bahan bunga matahari secara kreatif dan memiliki nilai estetika, dilakukan dengan pemberian materi secara daring dan praktik pembuatan kemasan secara langsung kepada peserta pelatihan sebanyak lima pertemuan. Kegiatan ini menyasar ke mitra masyarakat yang belum atau tidak produktif secara ekonomi seperti kelompok masyarakat binaan Kota Baru Parahyangan (KBP) yang tergabung dalam Kelompok Usaha Bersama (KUBE) Maju Bersama Sejahtera. Potensi yang dimiliki oleh KUBE Maju Bersama Sejahtera yang berada di Desa Bojonghaleuang, Kabupaten Bandung Barat adalah bunga matahari dan lebah madu. Pengolahan dan pemanfaatan biji bunga matahari sebagai material sabun herbal perlu ditunjang dengan usaha kreatif dari KUBE Maju Bersama Sejahtera untuk mengemas produk sabun bunga matahari secara unik, menarik, dan berdaya jual. Kegiatan pengabdian masyarakat ini berhasil memberikan wawasan tentang teknik kemasan produk sabun dari bunga matahari kepada KUBE Maju Bersama Sejahtera sebagai bekal keterampilan home industry yang dapat menunjang ekonomi rumah tangga. Hasil tersebut terlihat setelah mengikuti kegiatan, para peserta dapat membuat berbagai bentuk kemasan secara unik dan kreatif.
\end{abstract}

Katakunci: bunga matahari, community empowerment, kemasan, kreatif, sabun 


\begin{abstract}
Maranatha Christian University as a private university in Bandung has a work program that is reflected in the vision and mission of higher education tridharma. The vision and mission of Maranatha Christian University which is carried out through the fields of teaching, research and community service, one of which is focused on community empowerment programs and social problems around, involving several teaching staff (lecturers) from representatives of the Visual Communication Design Study Program and D-3 Art Design as a material formulator as well as a skills trainer or teacher as a form of social responsibility. The community service program which was initiated in the form of training on making soap product packaging from sunflower materials creatively and has aesthetic value, was carried out by providing materials online and practicing packaging directly to the training participants for five meetings. This activity is targeted at community partners who are not economically productive yet, such as the Kota Baru Parahyangan (KBP) assisted community groups that are members of the Maju Bersama Sejahtera Joint Business Group (KUBE). The potential of KUBE Maju Bersama Sejahtera in Bojonghaleuang Village, West Bandung Regency is sunflower and honey bee. The processing and utilization of sunflower seeds as herbal soap material needs to be supported by the creative efforts of KUBE Maju Bersama Sejahtera to package sunflower soap products in a unique, attractive, and marketable way. This community service activity succeeded in providing insight into the packaging technique for soap products from sunflower to the Maju Bersama Sejahtera Joint Business Group (KUBE) as a provision for home industry skills that can support the household economy. These results can be seen after participating in the activity, the participants can make various forms of packaging in a unique and creative way.
\end{abstract}

Keywords: community empowerment, creative, packaging, soap, sunflower

\section{PENDAHULUAN}

Latar belakang kegiatan pengabdian kepada masyarakat ini bermula dari adanya permohonan pelatihan kreativitas dari Kota Baru Parahyangan (KBP), Kabupaten Bandung Barat kepada Fakultas Seni Rupa dan Desain, Universitas Kristen Maranatha untuk memberikan kegiatan pelatihan kepada kelompok binaan masyarakat yang berada di Desa Bojonghaleuang yaitu Kelompok Usaha Bersama (KUBE) Maju Bersama Sejahtera, yang bergerak di bidang budi daya taman bunga matahari, pembuatan sabun bunga matahari, serta kegiatan-kegiatan lainnya yang berhubungan dengan bunga matahari. KUBE Maju Bersama
Sejahtera telah memproduksi sabun dari minyak biji bunga matahari dan biji tanaman bunga matahari sebanyak kurang lebih seratus bungkus setiap bulannya. Namun, jumlah produksi tersebut tidak selalu konsisten setiap bulannya karena biasanya dibuat berdasarkan pesanan untuk suvenir jika ada kunjungan pejabat atau tamu undangan dari pemerintah kabupaten ke Desa Bojonghaleuang maupun permintaan dari manajemen pihak Kota Baru Parahyangan.

Tujuan pelatihan yang diberikan tersebut diharapkan nantinya dapat menumbuhkan semangat kreativitas, kualitas, dan kemampuan ekonomi secara mandiri dari kelompok 
masyarakat binaan di Kota Baru Parahyangan dengan menggunakan material baru, material daur ulang dari sumber potensi di desa tersebut, maupun material lain yang masih dapat diolah seoptimal mungkin menjadi produk kreatif. Selain itu, nantinya setiap produk yang dihasilkan dapat berfungsi optimal dalam kehidupan sehari-hari bahkan berdaya jual atau nilai ekonomis.

Kegiatan pengabdian kepada masyarakat ini diambil dari contoh kegiatan terdahulu serta beberapa artikel jurnal yang dapat dijadikan sebagai referensi pada pelatihan ini. Contoh yang diambil berupa jurnaljurnal mengenai potensi masyarakat desa yang salah satunya berjudul "Pemberdayaan Kreatifitas Masyarakat Desa Bringen Melalui Program Kewirausahaan Berbasis Pengembangan Potensi Lokal" hasil kegiatan pengabdian yang dilakukan oleh Hendy Widiastoeti dan Novi Theresia Kiak dari Universitas 17 Agustus 1945 Surabaya pada tahun 2018 yang menjelaskan pengaruh sumber daya alam suatu desa sebagai potensi masyarakatnya dalam mengembangkan perekonomian keluarga (Widiastoeti dan Kiak, 2018).

Potensi kebun bunga matahari dan lebah madu yang dimiliki Desa Bojonghaleuang menjadi target utama bagi Fakultas Seni Rupa dan Desain, Universitas Kristen Maranatha melalui pengembangan life skill dan kreativitas melalui pelatihan yang bermanfaat dan berkelanjutan bagi kelompok binaan masyarakat Kota Baru Parahyangan (KBP) yakni pembuatan kemasan sabun bunga matahari.

\section{METODE}

Kegiatan pengabdian kepada masyarakat ini terdiri atas dua macam pelatihan yakni pembuatan kemasan sabun bunga matahari dan pembuatan souvenir berisi biji bunga matahari. Namun, yang akan dibahas lebih mendalam pada artikel ini adalah terkait dengan pelatihan pembuatan kemasan sabun bunga matahari.

Adapun detail pelaksanaan kegiatan pengabdian kepada masyarakat ini sebanyak lima sesi pelatihan dengan rincian metode $5 \mathrm{~W}+1 \mathrm{H}$ sebagai berikut:

1. What: kegiatan pengabdian kepada masyarakat yang dilakukan adalah pelatihan pembuatan kemasan sabun bunga matahari kepada Kelompok Usaha Bersama (KUBE) Maju Bersama Sejahtera.

2. Who: peserta kegiatan pelatihan diikuti oleh remaja karang taruna dan beberapa ibu rumah tangga yang terlibat dalam Kelompok Usaha Bersama (KUBE) Maju Bersama Sejahtera sebanyak 30 orang.

3. Why: kegiatan pengabdian kepada masyarakat ini dilakukan atas permintaan dari Kota Baru Parahyangan selaku Pembina dari Kelompok Usaha Bersama (KUBE) Maju Bersama Sejahtera untuk memberikan pembekalan ilmu dan wawasan terkait kreativitas mendesain kemasan sabun herbal dari bunga matahari.

4. Where: tempat diadakan kegiatan pengabdian kepada masyarakat ini adalah Desa Bojonghaleuang, Kabupaten Bandung Barat. 
5. When: pelaksanaan kegiatan pengabdian kepada masyarakat ini dilakukan sebanyak lima pertemuan yakni 19, 26, 27 Agustus serta 2,3 September 2020.

6. How: kegiatan pengabdian kepada masyarakat ini dilakukan secara online pada saat pemberian materi dan onsite pada saat pemberian material dan praktik oleh peserta pelatihan.

Kegiatan pengabdian kepada masyarakat dimulai pada Rabu, 19 Agustus 2020 melalui prosesi pembukaan yang dihadiri oleh Kepala Desa Bojonghaleuang, tim penanggung jawab dari Kota Baru Parahyangan, serta tim dosen Fakultas Seni Rupa Desain Universitas Kristen Maranatha dengan melakukan perkenalan dan pengantar materi pelatihan kepada peserta. Pertemuan berikutnya dilakukan pada Rabu, 26 agustus 2020 dengan memberikan materi yang difokuskan tentang kemasan dan elemen desain. Selanjutnya pada Kamis, 27 Agustus 2020 tim dosen berkunjung ke Desa Bojonghaleung untuk langsung memberikan materi secara praktik tentang pembuatan kemasan sabun kepada peserta. Pada Rabu, 2 September 2020 dilakukan praktik pembuatan kemasan suvenir biji bunga matahari oleh peserta dengan panduan dari tim dosen. Dan terakhir pada Kamis, 3 September 2020 dilakukan kegiatan penutupan acara pelatihan disertai pemberian reward kepada peserta pelatihan yang hasil karyanya dinilai paling kreatif dan unik.

Sedangkan peralatan dan bahan untuk kegiatan pengabdian kepada masyarakat telah disiapkan oleh tim dosen Fakultas Seni Rupa Desain yakni berupa modul kit berisi pola kemasan, bahan kertas beraneka jenis, pita, kain pengikat, tali, lem, dan gunting.

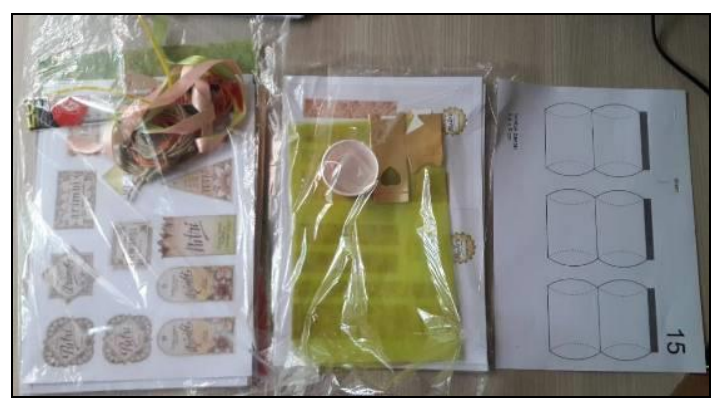

Gambar 1. Modul Kit Pelatihan

Selama tahap persiapan pengabdian kepada masyarakat ini ditemui beberapa kendala seperti koordinasi dengan pihak Kota Baru Parahyangan yang beberapa kali diadakan secara daring melalui aplikasi Zoom karena masa Pembatasan Sosial Berskala Besar (PSBB) yang diberlakukan di Kota Bandung. Sehingga tim dosen, dibantu mahasiswa, kurang mendapatkan detail kebutuhan untuk materi pelatihan karena terkendala pandemi COVID-19 yang sedang terjadi. Akibatnya untuk kegiatan pengabdian kepada masyarakat pembuatan kemasan sabun bunga matahari dilakukan dengan metode trial and error terlebih dahulu bersama tim dosen dan mahasiswa selama beberapa kali sebelum kegiatan pelatihan diselenggarakan.

\section{HASIL DAN PEMBAHASAN}

\section{Profil Desa Bojonghaleuang}

Bagi sebagian warga Bandung, belum banyak yang mengenal Desa Bojonghaleuang, terlebih desa ini merupakan salah satu bagian wilayah 
dari Kabupaten Bandung Barat (KBB) berada di bawah Kecamatan Saguling, yakni kecamatan baru hasil dari pemekaran wilayah Kecamatan Batujajar.

Letak Desa Bojonghaleuang yang berada berdekatan di bagian dalam kompleks Kota Baru Parahyangan membuat akses ke desa ini cukup sulit dijangkau dari jalan utama arah Padalarang-Cimahi, seperti pada Gambar 2. Oleh sebab itu, tim CSR (Corporate Social Responsibility) Kota Baru Parahyangan bekerjasama dengan perangkat Desa Bojonghaleuang membentuk KUBE Maju Bersama Sejahtera melalui potensi kebun bunga matahari dengan berbagai varietas (Herlina et al., 2019) dan lebah madu sebagai basis usaha pemberdayaan perekonomian masyarakat Desa Bojonghaleuang (Sugita, 2017).

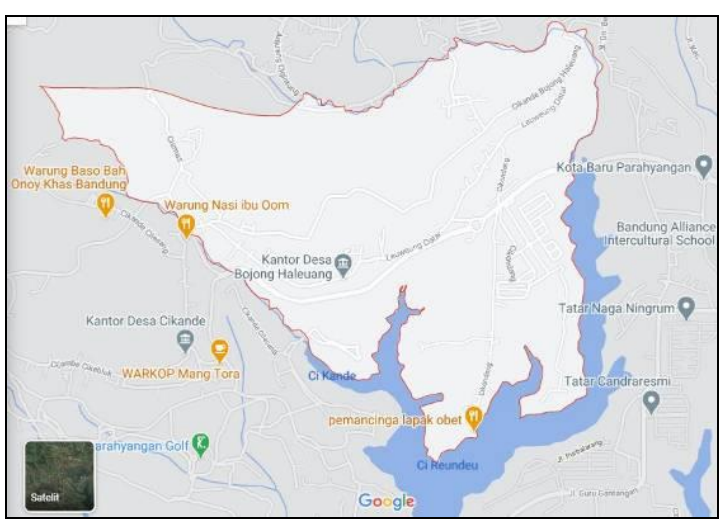

Gambar 2. Peta Desa Bojonghaleuang (Google Maps, 2020)

\section{Potensi Bunga Matahari}

Bunga matahari (Helianthus annuus L.) atau dikenal juga dengan nama tanaman heliotropik yakni tanaman yang tumbuh mengikuti arah matahari, termasuk ke dalam family Asteraceae (Saini dan Sharma, 2011). Bunga matahari termasuk tanaman yang dapat dimanfaatkan hampir seluruh bagian tanamannya. Berikut ini adalah manfaat dari bunga matahari yang disarikan dari (Juniarti dan Herdiana, 2017):

1. Berfungsi sebagai tanaman hias

2. Tanaman penarik serangga penyerbukan, dalam hal ini lebah madu, bagi tanaman lain

3. Memiliki varietas beragam

4. Penghasil minyak nabati (dari bijinya) yang setara kualitasnya dengan minyak zaitun (Katja, 2012)

5. Berfungsi sebagai tanaman obat, terutama bagian bunga-bunga kecil di bagian dalam bunga besar (inflorescence) dan kelopak bunganya

6. Biji bunga matahari jika dikeringkan menjadi kuaci, cemilan sehat rendah kolesterol.

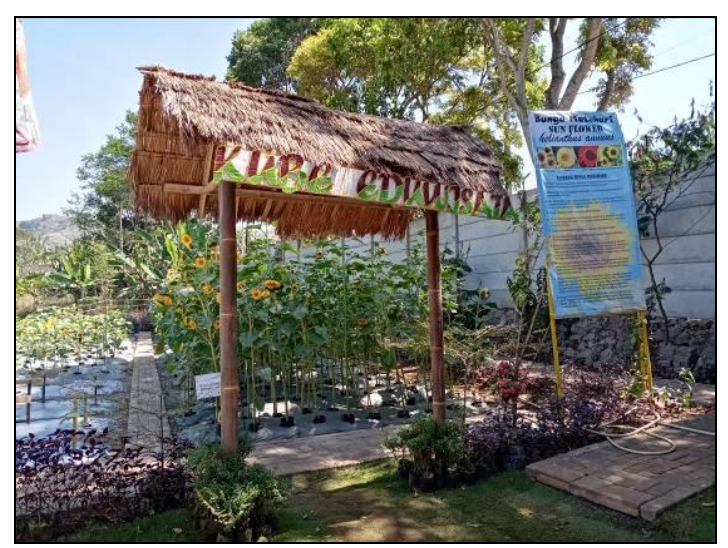

Gambar 3. Kebun Bunga Matahari Yang Berada di Workshop KUBE Desa Bojonghaleuang 


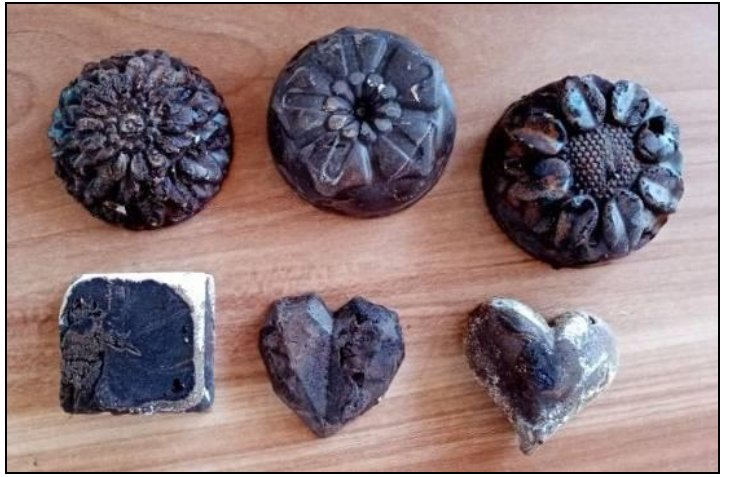

Gambar 4. Sabun Dari Biji Bunga

Matahari Sebagai Potensi Industri

Kreatif Desa Bojonghaleuang

Sabun dari biji bunga matahari yang dibuat oleh KUBE Desa Bojonghaleuang ini termasuk ke dalam sabun handmade berbentuk sabun padat atau hard soap (Widyasanti et al., 2016) dengan menggunakan bahan baku minyak dari biji bunga matahari. Pembuatan sabun padat ini sangat ramah lingkungan, tidak menyebabkan iritasi kulit, serta berkhasiat dari bahan aktif herbalnya itu sendiri yakni minyak dari biji bunga matahari.

Selain sabun berbahan biji bunga matahari, KUBE Desa Bojonghaleuang juga berkreasi membuat sabun berbahan kopi karena memiliki beberapa manfaat untuk kecantikan seperti menghaluskan kulit, menetralkan kulit yang mengalami iritasi, memberi nutrisi, mengangkat sel kulit mati, serta memperbaiki jaringan kulit yang rusak (Yeni dan Nining, 2018).

\section{Kegiatan Pengabdian Kepada Masyarakat: Kemasan Sabun Bunga Matahari}

Kegiatan pengabdian kepada masyarakat berupa pelatihan pembuatan kemasan sabun kepada anggota Kelompok Usaha Bersama (KUBE) Maju Bersama Sejahtera diikuti oleh sekitar 30 orang yang terdiri atas ibu rumah tangga, karang taruna (siswa SMA, SMK, mahasiswa), dan karyawan. Materi pelatihan yang diberikan adalah pelatihan pembuatan kemasan sabun herbal bunga matahari (untuk suvenir).

$$
\text { Kegiatan pelatihan yang }
$$
dilakukan oleh tim dosen Fakultas Seni Rupa Desain Universitas Kristen Maranatha sejalan dengan kegiatan pengabdian kepada masyarakat yang dilakukan sebelumnya yakni bertujuan mengasah kreativitas berolah rupa melalui eksplorasi tanpa henti, berinisiatif menemukan ide dan cara baru untuk membuat sesuatu atau karya, sebagaimana visi dan misi Fakultas Seni Rupa Desain, Universitas Kristen Maranatha dalam menjalankan Tridharma Perguruan Tinggi (Aryani et al., 2020).

\section{Sebagaimana}

kegiatan pengabdian kepada masyarakat yang dilakukan (Lestari, 2020) menyatakan bahwa perlu dilakukan pemetaan sosial industri kreatif suatu daerah berdasarkan potensi yang dimilikinya. Ekonomi kreatif akan menjadi hal yang potensial jika didukung tiga hal berupa creative knowledge (pengetahuan yang kreatif), skilled worker (pekerja yang berkemampuan), labor intensive (kekuatan tenaga kerja) yang dapat digunakan dalam banyak ruang pada industri produk kreatif yang terus berkembang di Indonesia, seperti: crafts, advertising, publishing and printing, television and radio, architecture, music, design, dan fashion (Ilhamuddin et al., 2018). 
Adapun ekonomi kreatif yang hendak dikembangkan oleh tim Corporate Social Responsibility (CSR) Kota Baru Parahyangan bersama tim dosen Fakultas Seni Rupa Desain, Universitas Kristen Maranatha di Desa Bojonghaleuang adalah bidang crafts, terutama sabun herbal dari bunga matahari yang dikemas secara unik dan menarik. Oleh karena itu, tim dosen dibantu mahasiswa Program Studi Desain Komunikasi Visual (DKV), Universitas Kristen Maranatha menyiapkan materi pelatihan terlebih dahulu menggunakan beberapa macam material kertas dan bahan pendukung seperti terlihat pada Gambar 5.

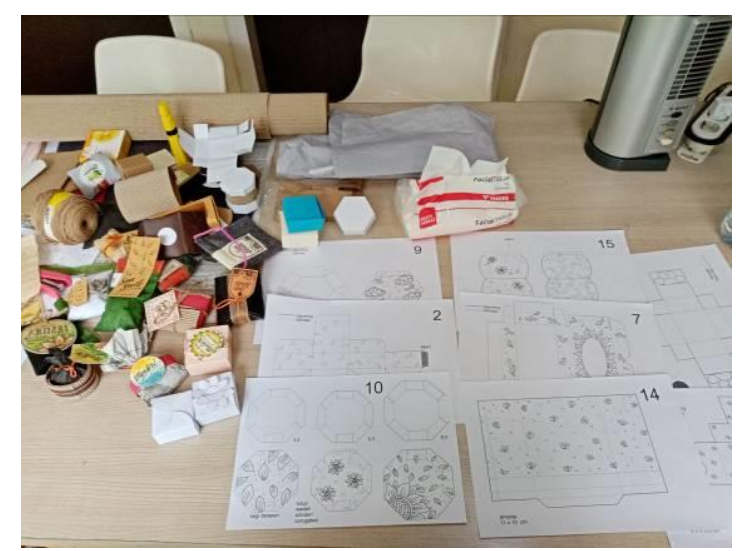

Gambar 5. Persiapan Pelatihan

Pada tahap persiapan tersebut, tim dosen menyiapkan 14 modul pola kemasan sabun sebagai bahan pelatihan. Dari keempat belas modul pola kemasan tersebut dapat digunakan oleh seluruh peserta pada saat bereksperimen membuat kemasan sabun. Namun, adanya keterbatasan waktu pelaksanaan pengabdian kepada masyarakat yakni hanya berlangsung dua jam untuk setiap sesi pelatihan, maka peserta dapat memilih modul pola kemasan sabun yang mereka inginkan.
Selanjutnya, peserta dapat mengembangkan pola kemasan yang diberikan tersebut sesuai kreativitas dan material pendukung lain yang dimiliki.

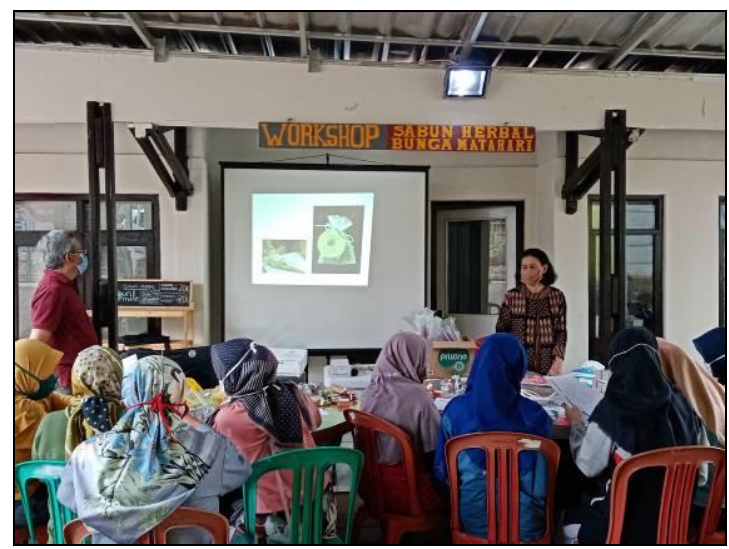

Gambar 6. Suasana Pelatihan Secara Onsite Oleh Tim Dosen FSRD

Terkait dengan kondisi kebiasaan hidup baru (new normal) saat ini di wilayah Kabupaten Bandung Barat, khususnya di Desa Bojonghaleuang, maka metode pelatihan yang diterapkan adalah kombinasi metode onsite dan metode pelatihan secara daring. Pelatihan daring (online) diberikan selain akibat kondisi pandemi COVID-19 yang sedang terjadi, juga cara ini dinilai efektif oleh tim dosen karena dapat menyampaikan materi secara interaktif dengan visualisasi video melalui aplikasi video conference Zoom. Sedangkan tempat pelatihan onsite diselenggarakan di workshop binaan Kota Baru Parahyangan yang ada di Desa Bojonghaleuang.

Metode pelaksanaan kegiatan pengabdian kepada masyarakat yang dilakukan dengan dua cara tersebut diharapkan mampu memberikan cukup pengetahuan dan skill baru kepada peserta pelatihan yang seluruhnya berasal dari Desa 
Bojonghaleuang. Metode pelatihan online dilakukan sebanyak dua kali pertemuan dengan memberikan materi tentang desain grafis dan teknik dasar kemasan. Kemasan yang diperkenalkan dalam pelatihan ini adalah jenis kemasan tambahan atau secondary package (Susetyarsi, 2012). Selain teknik dasar kemasan, juga disampaikan tentang peran desain kemasan (Mukhtar dan Nurif, 2015) yang menarik sebagai salah satu media komunikasi dan informasi suatu produk (Rosalina et al., 2010). Sedangkan pelatihan onsite dilakukan oleh tim dosen kepada peserta untuk dapat langsung memberikan pengarahan melalui praktik.

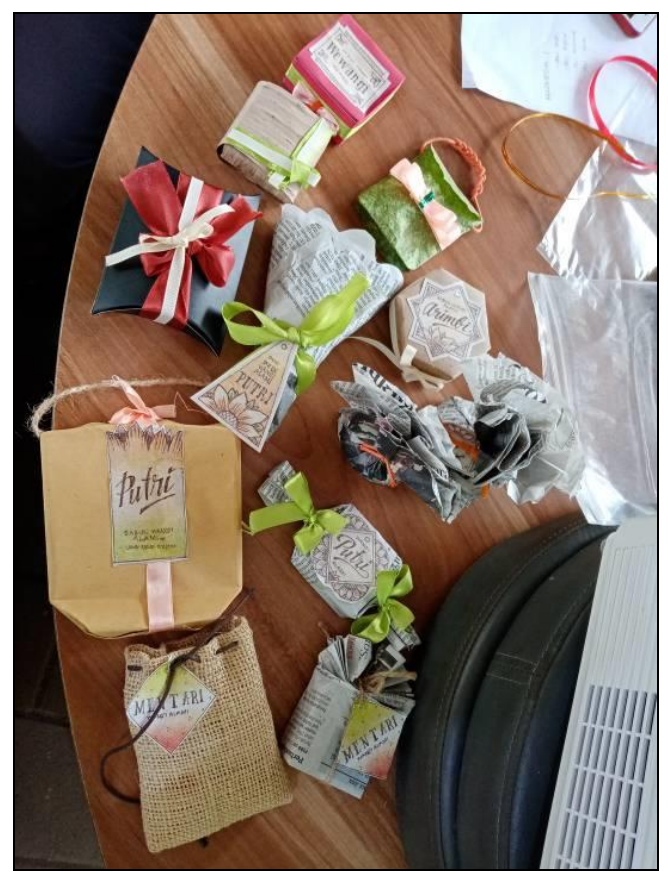

Gambar 7. Beberapa Hasil Kreasi Kemasan Sabun Oleh Peserta (Bag.1)

Secara keseluruhan, pelatihan pembuatan kemasan sabun ini memperkenalkan pentingnya atribut desain produk, bahan kemasan, dan bentuk kemasan terhadap isi produk, dalam hal ini adalah sabun berbahan minyak bunga matahari dan juga kopi
(Mufreni, 2016). Bentuk kemasan berpengaruh terhadap sisi psikologis konsumen, terlebih jika memiliki desain menarik dan terkesan berukuran besar akan meningkatkan daya tarik konsumen untuk membeli. Namun, desain yang dibuat berdasarkan tema tertentu seperti hari raya maupun pergantian tahun akan memiliki terkesan lebih menarik ketika dikemas menjadi bundle product sehingga terkesan lebih hemat (Feiz, et al., 2014).

Pada pertemuan akhir dari kegiatan pelatihan kepada masyarakat, tim dosen melakukan evaluasi singkat dengan cara sharing oleh peserta. Beberapa peserta pelatihan, terutama kalangan ibu rumah tangga, merasakan manfaat dari pelatihan ini cukup banyak dari semula kurang memahami tentang fungsi dan bentuk kemasan sabun yang dibuat selama ini, menjadi lebih mengerti dan memahami teknikteknik baru dalam membuat kemasan sabun yang lebih menarik untuk dijadikan suvenir.

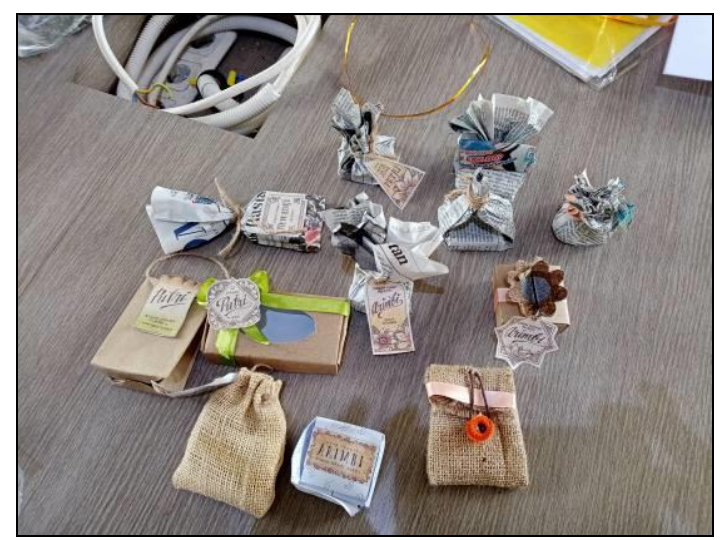

Gambar 8. Beberapa Hasil Kreasi Kemasan Sabun Oleh Peserta (Bag.2)

\section{KESIMPULAN}

Berdasarkan hasil kegiatan pengabdian kepada masyarakat yang 
dilakukan di Desa Bojonghaleuang, Kabupaten Bandung Barat, maka dapat diketahui bahwa potensi pemberdayaan masyarakat melalui industri kreatif yang paling banyak memberikan kontribusi pada perekonomian adalah kriya (crafts). Adanya potensi kebun bunga matahari sebagai penghasil bunga matahari, lokasi wisata selfie, serta penghasil lebah madu dalam satu tempat di Desa Bojonghaleuang dapat lebih dikembangkan lagi di masa mendatang. Namun, sebelumnya pengurus Desa Bojonghaleuang harus memperbaiki serta meningkatkan infrastruktur, fasilitas, dan sumber daya manusia terlebih dahulu.

Pengabdian masyarakat ini bertujuan untuk membuat hasil kemasan produk sabun dari bunga matahari yang ditujukan untuk kelompok masyarakat binaan di Kota Baru Parahyangan yang dapat didayagunakan kembali dalam keseharian mereka, serta menjadi bekal keterampilan home industry sebagai penunjang ekonomi rumah tangga. Seluruh peserta pelatihan yang semula tidak memiliki pengetahuan tentang kemasan, setelah mengikuti kegiatan pengabdian menjadi dapat mempraktikkan ilmu tentang kemasan yang telah diperoleh secara langsung. Hasil dari kreativitas peserta pelatihan cukup unik dan bervariasi.

Oleh karena itu, untuk kegiatan pengabdian kepada masyarakat selanjutnya, diharapkan dapat membahas lebih detail dan mendalam mengenai pengembangan desain kemasan serta upaya pemasaran produk sabun bunga matahari hasil budidaya Kelompok Usaha Bersama (KUBE) Maju Bersama Sejahtera supaya dapat lebih diketahui masyarakat di luar Desa Bojonghaleuang melalui sosialisasi media sosial. Kegiatan ini pun dinilai mampu mencapai target yakni dapat menciptakan masyarakat yang mandiri dan mampu berkarya atau wirausaha secara kreatif dengan memanfaatkan material di sekitar mereka untuk diolah menjadi produk yang memiliki nilai estetika bahkan nilai ekonomis sebagai penunjang kemandirian pemberdayaan masyarakat Desa Bojonghaleuang.

\section{DAFTAR PUSTAKA}

Aryani, D.I., Putri, A.W.A., \& Tan, I. J. (2020). Pemberdayaan Ekonomi Kreatif Rumah Tangga Melalui Kreativitas Pemanfaatan Kaus Bekas dengan Teknik Tie Dye. Abdimas Unwahas, 5(1), 45-51.

Feiz, D., Zarei, A., \& Rezaei, B. (2014). Effect of Packaging on Purchase Intention of Consumer (Case Study: Date Products in Shiraz). Arth Prabhand: A Journal of Economics and Management, 3(11), 236-246.

Herlina, D., dan Ardiarini, N.R. (2019). Keberhasilan Persilangan Pada Bunga Matahari (Helianthus annuus L.). Jurnal Produksi Tanaman, 7(1), 47-52.

Ilhamuddin, M., Rusminah, H., \& Ahyar, M. (2018). Strategi Pengembangan Industri Kreatif Sektor Kerajinan Perhiasan Mutiara Di Kota Mataram. JMM UNRAM, 7(1), 58-69.

Juniarti, R., dan Herdiana, Y. (2017). 
Aktivitas Ekstrak Helianthus annuus L. Farmaka, 15(2), 195199.

Katja, D.G. (2012). Kualitas Minyak Bunga Matahari Komersial dan Minyak Hasil Ekstraksi Biji Bunga Matahari (Helianthus annuus L.). Jurnal Ilmiah Sains, 12(1), 59-64.

Lestari, B. (2020). Pemetaan Sosial Industri Kreatif Kecamatan Kedungkandang Kota Malang. Jurnal Kewirausahaan Dan Bisnis, 25(1), 37-42.

Mufreni, A.N.F. (2016). Pengaruh Desain Produk, Bentuk Kemasan dan Bahan Kemasan Terhadap Minat Beli Konsumen (Studi Kasus Teh Hijau Serbuk Tocha). Jurnal Ekonomi Manajemen, 2(2), 48-54.

Mukhtar, S., dan Nurif, M. (2015). Peranan Packaging Dalam Meningkatkan Hasil Produksi Terhadap Konsumen. Jurnal Sosial Humaniora, 8(2), 181-191.

Rosalina, Y., Alnopri, P. (2010). Disain Kemasan Untuk Meningkatkan Nilai Tambah Madu Bunga Kopi Sebagai Produk Unggulan Daerah. Jurnal Agro Industri, 2(1), 8-13.

Saini, S., dan Sharma, S. (2011). Helianthus annuus (Asteraceae): A Review. International Journal of Pharma Professional's Research, 2(4), 465-470.

Sugita, A. (2017). Pemetaan Sosial Potensi Wisata Waduk Saguling di Desa Bojonghaleuang, Kecamatan saguling, Kabupaten Bandung Barat.
Susetyarsi, T. (2012). Kemasan Produk Ditinjau Dari Bahan Kemasan, Bentuk Kemasan dan Pelabelan Pada Kemasan Pengaruhnya Terhadap Keputusan Pembelian Pada Produk Minuman Mizone di Kota Semarang. Jurnal STIE Semarang, 4(3), 19-28.

Widiastoeti, H., \& Kiak, N. T. (2018). Pemberdayaan Kreatifitas Masyarakat Desa Bringen Melalui Program Kewirausahaan Berbasis Pengembangan Potensi Lokal. Jurnal Abdikarya: Jurnal Karya Pengabdian Dosen Dan Mahasiswa, 1(2), 127-129.

Widyasanti, A., Putri, S.H., dan Dwiratna, S.N.P. (2016). Upaya Pemberdayaan Masyarakat Melalui Pelatihan Pembuatan Produk Sabun Berbasis Komoditas Lokal di Kecamatan Sukamantri Ciamis. Dharmakarya: Jurnal Aplikasi Ipteks Untuk Masyarakat, 5(1), 29-33.

Yeni dan Nining. (2018). Pembuatan Sabun Kopi sebagai Produk Souvenir Komoditas Lokal di Desa Kaliaren Kabupaten Kuningan. Jurnal SOLMA, 7(2), 233-239. 